$2(a)$ is supposed to be maintained throughout the reaction; the rate-determining step $2(b)$ requires the intervention of the base group at the end of the chain upon which $E$ is situated, but this does not, of course, appear in the kinetic equations. The products in $2(b)$ are carbon dioxide and a phenylalanine residue which becomes joined to the terminal base group. The kinetic behaviour is quite different from that observed with the normal propagation reaction.

The process giving rise to the chain effect may therefore be visualized as the growth of one polymer on the surface of another in solution. It has analogies with heterogeneous reactions at interfaces. Of greater interest is the possible analogy with enzymic reactions. The dependence of the rate of the polymerization reaction upon the experimental variables, which is usually of the form shown in Fig. 1, resembles that found with enzymic reactions, and indeed the scheme (2) is similar to the simple Michaelis-Menten mechanism. The importance of the resemblances between the two types of system should become clearer with further work with other polymers and reactants.

Research Laboratory,

D. G. H. Batlard

C. H. BAMFORD

Courtaulds, Ittd.,

Maidenhead, Berks. Dec. 20.

${ }^{1}$ Ballard and Bamford, Proc. Roy. Soc., A, 223, 495 (1954).

\section{Carbohydrases in Blow-fly Larvæ}

HoBson $^{1}$ showed that glycerol and/or dried preparations of the gut and salivary glands of Lucilia sericata Meig. showed strong proteinase activity but very little carbohydrase activity, only starch being hydrolysed, whereas maltose, sucrose and lactose were not hydrolysed at all. Since that report, these results have been quoted ${ }^{2}$ to support the plausible example of adaptation, wherein larval and adult blowflies are assumed to possess digestive ability corresponding to their diet. Thus larvæ feeding on a protein-rich diet are adequately provided for because the gut shows strong proteolytic activity and the lack of carbohydrases is of no consequence. The reverse picture is presented in adult blow-flies which feed principally on carbohydrates; very active carbohydrases are present but only relatively weak proteinases.

However, Evans ${ }^{3}$ has recently established that gut tissues from the larvæ of Calliphora erythrocephala Meig. are able to hydrolyse a wide range of carbohydrates, there being little difference in this respect between larvæ and adults. Using the same techniques, it has now been demonstrated that Lucilia sericata larvæ are also capable of hydrolysing a wide range of carbohydrates. The salivary glands or gut tissues were incubated on a welled microscope slide in buffered substrate $(p H$ 6.8) which had previously been saturated with toluene. Hydrolysis of nonreducing substrates was readily detected by placing the slides on a hot plate after the addition of Benedict's sugar reagent and noting the appearance of red cuprous oxide. Any change in sugar content of reaction mixtures with reducing substrates was determinod by paper chromatographic analyses of samples of the reaction mixture before and after incubation. In all experiments suitable controls using denatured tissues were always employed.
The following substrates were hydrolysed by salivary gland and mid-gut tissue from Lucilia larvæ: maltose, sucrose, trehalose, $\alpha$-methyl galactoside, raffinose, melezitose, starch; whereas the following were not hydrolysed : $\alpha$-methyl glucoside, lactose, melibiose, cellobiose, cellulose.

These results, which are similar to those obtained for Calliphora, are of interest in relation to the problems of carbohydrase specificity. Fraenkel explained the ability of adult Calliphora to digest a range of carbohydrates by assuming the bond-specificity concept of Weidenhagen ${ }^{5}$. So far as the disaccharides and trisaccharides were concerned, only enzymes capable of splitting $\alpha$-glucoside and $\alpha$-galactoside linkages were required to be present. However, the carbohydrase activity of larval blow-fly tissues cannot be accounted for so easily because : (1) $\alpha$-methyl glucoside is not hydrolysed, unlike all the other sugars containing an $\alpha$-glucoside bond, namely, maltose, sucrose, trehalose and melezitose; (2) $\alpha$-methyl galactoside is hydrolysed, but melibiose, another $\alpha$-galactoside, is not. It is clear that the properties of larval blow-fly carbohydrases do not completely exemplify Weidenhagen's hypothesis of bond specificity, the over-generalized nature of which has been criticized more recently ${ }^{8}$. Much more information about the properties of animal carbohydrases is necessary to give a satisfactory explana. tion of the ability to digest certain carbohydrates and not others in terms of bond specificity or otherwise.

\section{W. A. L. Evans}

$$
\text { J. MARsden }
$$

Dept. of Zoology and Comparative Anatomy, University College,

Cardiff.

Nov. 8.

${ }^{1}$ Hobson, R. P., J. Exp. Biol., 8, 109 (1931).

"Wigglesworth, V. B., "Principles of Insect Physiology", 331 (4th edit., Methuen, London, 1950). Day, M. F., and Waterhouse D. "In

3 Evans, W. A. L., Exp. Parasit. (in the press).

- Fraenkel, G., J. Exp. Biol., 17, 18 (1940).

'Weidenhagen, R., Erg. Enzymforsch., 1, 68 (1932).

- Pigman, W. W., “Adv. Enzymology”, 4, 41 (1946). Gottschalk, G. A., “The Enzymes", 1, Part 1, 551 (Academic Press, New York, 1950).

\section{Comparative Anticstrogenic Potencies of Progesterone and $17 \alpha-H$ ydroxyprogesterone}

Progesterone is known to be not only a progestational compound but also to exert various antiœestrogenic actions : it prevents œestrogen-induced abdominal fibroids, œstrogen-induced growth of the myometrium, and cstrogen-induced excessive luteinization ${ }^{1}$. The antioestrogenic potency of progesterone is diminished by oxidation at $\mathrm{C}_{21}$, $\mathrm{C}_{11}$ and $\mathrm{C}_{17}{ }^{2,3}$. The validity of this rule has been demonstrated by comparing progesterone with $\mathrm{C}_{11^{-}}$derivatives such as $11 \beta$-hydroxyprogesterone and 11-keto-progesterone, and with a $\mathrm{C}_{21}$-derivative such as deoxycorticosterone. As to oxidation at $\mathrm{C}_{17}$, comparison was made between deoxycorticosterone and Reichstein's compound $S$ or 17 $\alpha-\mathrm{OH}-11$-deoxycorticosterone ${ }^{2}$. Thus the conclusion as to loss of antiœestrogenic potencies due to oxidation at $\mathrm{C}_{17}$ in the $\alpha$-position has been so far an indirect one; $\mathbf{a}$ comparison of progesterone with $17 \alpha$-hydroxyprogesteron $\Theta$ was still lacking. Results with the latter are given in the present communication. 